Western University

Scholarship@Western

Education Publications

Education Faculty

2007

\title{
Decentralisation and Education in Africa: The Case of Uganda
}

Immaculate Kizito Namukasa

The University of Western Ontario, inamukas@uwo.ca

Ronald Buye

Makerene University, Uganda

Follow this and additional works at: https://ir.lib.uwo.ca/edupub

Part of the Education Commons

Citation of this paper:

Namukasa, I. K.,\& Buye, R. (2007). Decentralization and Education in Africa: The Case of Uganda. Canadian and International Education, 36(1), 93-116. 
Decentralisation and Education in Africa: The Case of Uganda

Immaculate K. Namukas and Ronald Buye

\section{Abbreviations}

CC Coordinating Center

CAO Chief Administrative Officer

CCT Coordinating Center Tutor

DEO District Education Officer

DIS District Inspector of Schools

DECBP District Education Capacity Building Programme

EMIS Education Management Information System

ESIP Education Strategic Investment Plan

MoES Ministry of Education and Sports, Uganda

MoFED Ministry of Finance and Economic Development

MoLG Ministry of Local Government

NCDC National Curriculum Development Center

NRM National Resistance Movement

PAF Poverty Alleviation Fund

PTA Parent and Teacher Association

PTC Primary Teacher College

SFG School Facilities Grant

SMC School Management Committee

TDMS Teacher Development and Management System

UPE Universal Primary Education 


\section{Introduction}

Many countries have decentralized their education systems. In some countries, especially developing countries, educational decentralisation is part of a larger exercise of devolving all public services. In sub-Saharan Africa, the factors that encourage centralization include positive effects such as political stability and economic development, as well as push factors like existing regional inequalities and inadequacies, real and perceived, of central governments. Donor communities are encouraging these poor countries to decentralize and/or privatize public services. Among these countries, Uganda has proceeded quickly in an almost-all-atonce decentralisation strategy.

The current Ugandan government administered some decentralisation in the areas under its control in the early 1980s while it was still a guerilla force called the National Resistance Movement. After it came to power in 1986, the government adopted countrywide decentralisation, cost sharing and privatization as policies supported by multinational donor agencies, such as the World Bank (WB) and the United Nations Development Programme (UNDP). To date, most government-administered services (except a few, such as the police and the army) that have not yet been privatized are decentralized. These include primary healthcare, education, basic 
services in water and sanitation, feeder roads and agricultural extension. Decentralisation has changed the delivery of public services, particularly education.

Education has been decentralized to local governments beginning with primary (equivalent to elementary) education. Many programs have been put in place to facilitate decentralisation of education service delivery. It appears that the decentralisation of education has been more effected at the elementary level than at other levels. In a way, decentralisation of administration among Ugandan districts can be seen as a re-introduction of the federalization or regionalization process, since before colonization tribal groups had some form of federalization under tribal kingdoms and/or chiefdoms.

In the Ugandan context, decentralisation is taken to mean the reassignment of some decision-making (management) authority, responsibility and tasks from the central government to the local governments. The legal, financial, administrative and political management of public functions has become the responsibility of the local community, under the leadership of the local councils (LCs). Decentralisation appears to be based on the governance idea of subsidiarity: matters should be handled by the smallest (or lowest) competent authority. Subsidiarity means that a central authority 
should have a subsidiary function, performing only those tasks which cannot be performed effectively at a more immediate or local level. Central authorities delegate management to sub-national, municipal or local units (Naidoo 2002). There are varying degrees to which this delegation happens, ranging from deconcentration at the lower end, through delegation, to devolution at the upper extreme.

Deconcentration involves the spatial relocation of decisionmaking; some administrative responsibility is transferred to lower level governments. Because it is the lowest form of decentralisation, deconcentration involves the transfer of tasks and responsibility, but not of authority (Hanson 1998; Naidoo 2002).

Under moderate decentralisation - delegation - the transferred decision-making authority may be withdrawn from the local government at the discretion of the central unit. Delegation involves the transfer of fiscal and administrative tasks, but not of political tasks.

When the highest degree of authority, which includes political and market responsibility for governing, is transferred to the local government, devolution is said to be taking place. Devolution involves the creation or strengthening, financially or legally, of subnational units of governments. Naidoo (2002) compares the status of education decentralisation in six sub-Saharan African countries 
DECENTRALISATION AND EDUCATION IN AFRICA

including Tanzania and Ghana. He identifies Uganda as the only example of devolution. Devolution of education goes hand in hand with the introduction of market forces to the system through privatization. In Uganda, elementary education was universalized in 1997. Plans are underway to universalize secondary education.

\section{Historical Background of Education Decentralisation in}

\section{Uganda}

As in other former colonies, Christian missionaries were in charge of founding, administering and funding schools in the early twentieth century. Missionary education was made possible with the help of local Ugandans, mainly traditional chiefs (Ssekamwa 1997). At the beginning, the colonial government did not involve itself in establishing, financing and administering schools. The missionaryfounded schools were built on Western models of education. A majority of these schools had coherent structures and strong religious traditions. During the economic and political instabilities, many missionary-founded schools were resilient to the inadequacies of the central government (Paige 2000).

Around 1920, the Uganda protectorate government gradually began to assist the missionaries in the provision of education. The 

central government began constructing public schools and aiding schools with grants. In 1963, the Education Act was passed to place all grant-aided schools under the control of the government. This progressively curtailed the control of schools by racial and religious bodies, but major differences remained among schools founded by different bodies. At present, all missionary-founded schools are jointly controlled by religious institutions and by the government through the Ministry of Education.

In 1970, a second Education Act was introduced to encourage the establishment of private schools in Uganda. This act streamlined the requirements and procedures for establishing and operating a private school (Ssekamwa 1997). A few more church-founded schools and a couple of international schools were established. Private colleges were also established. In 1997, elementary education was universalized beginning with grades $1-4$. The growth of private schools had been slow until this time. Several factors caused private education to grow exponentially in the late 1990s. These include economic and political stability, further privatization, recovery from war, increased school enrollments and Universal Primary Education (UPE). Many schools are now owned by individuals or groups of persons. Private schools for children from middle-class and affluent families are better-equipped and staffed with more affluent teachers. 
There are also many impoverished private schools for students of low socio-economic status and/or with low academic achievement. These schools are poorly equipped and staffed with ill-paid teachers in order to keep the tuition cost affordable for parents. Until Universal Secondary Education is implemented, there will be a steady growth of private secondary schools that survive on meager resources. Very few public schools have been built even at the secondary level where there is an increasing need. With the commercialization of higher education, private universities and colleges have emerged, to supplement what used to be exclusively public-funded tertiary education. Decentralisation of the Ugandan education system is closely linked to the universalization of basic education and to the growing privatization and commercialization of higher education.

Education decentralisation in Uganda was not an educational reform, as it was in other countries such as Sri Lanka and Australia. Educational leaders did not forward the decentralisation proposal. The Ugandan process of decentralisation was driven by national political will rather than by educational reform.

\section{Decentralizing Educational Administration in Uganda}

In 1986, the National Resistance Movement government put in place a new system of local governance called Resistance Councils that 
were later renamed LCs. The LC system is a five-level tiered system.

It progresses from the zone (village) level (I), through the parish (II), sub-county/division (III), county/sub-district (IV), and district/municipal (V) to the central government level. The first phase of the LC I to LC V tiered local governance was launched in 13 (out of the then 45) districts. Councils at lower levels have nine 5-yearly elected councilors including a chairman, a vice chairman and secretaries representing women, youth and security. Starting from LC III and going up to LCV, the councils are administrative bodies, in addition to being political and legal bodies. LCIII is headed by the sub-county chief in rural areas and by town clerks in towns. The district administration, LCV in the capital city, is headed by the mayor; elsewhere, it is headed by an administrative officer.

Councilors, especially at the lower levels, are unpaid volunteers. ${ }^{1}$ Starting at LC II and going up, the district service commission (DSC) recruits and remunerates administrative personnel like the sub-county chiefs and the parish council agents.

In 1993, the Local Government (Resistance Councils) Statute was passed to provide for the transfer of powers and resources to LCs.

1 The present government is considering formally remunerating councilors at LC I and LC II levels. 
The 1993 Statute provided the firm legal basis for the earlier practices of the local council system, and rationalized the five-tiered local governance. It also clarified that public servants are answerable to their respective LCs (Saito 2000).

Currently, the broader decentralisation process in Uganda is guided by the 1997 Local Government Act. With this Act, Resistance Councils were renamed LCs. Education was listed as one of the major public functions for which the highest level in the local hierarchy, the District Council, was to be directly responsible (Local Government Act, 1997, Article 176(2) of the Constitution, Sect. 97 \& 98). In the Act, the levels of education that were to be decentralized were listed as nursery, elementary, secondary, trade education, special education and technical education. Higher and university education continued to lie outside the governance of LCs. The objectives of the Act were as follows:

- To give full effect to the decentralisation of functions, powers, responsibilities and services at all levels of local governments

- To ensure democratic participation and control over decisionmaking by the people concerned

- To establish a democratic, political and gender-sensitive 
administrative set-up in local governments

- To establish sources of revenue and financial accountability

- To provide for the election of LCs

\section{The Ugandan Education System Prior to Decentralisation}

Before decentralisation, all the systems were centralized under the national government and the district/municipality governments. The districts implemented policies chosen by the central government. They carried out activities on behalf of the ministry of education. Key personnel included the Permanent Secretary and the national Chief Education Officer (CEO) at the national Ministry of Education level, and the District Education officer (DEO) at the district level. Lugumba and Ssekamwa (1973) observe that during that time the key person who administered the educational service of elementary schools in any district was the DEO, who was the secretary to the district education committee. With the assistance of one or two assistant inspectors of schools attached to his office, the DEO advised elementary school head teachers on matters concerning timetables and syllabuses. The DEO was, on behalf of the national CEO, responsible for the inspection of elementary schools, for inservice teacher education, for professional development workshops and courses, the transfer of teachers, and the administration of grants 
for school buildings, equipment, furniture and funds for elementary school teachers' salaries. The DEO was answerable to the Permanent Secretary.

The two-tiered centralized governance of education posed a problem for districts far away from the main national administrative city, Kampala. Worse still, many local areas were far from their district headquarters. Personnel at the district level were limited. The unequal access and other inequities were aggravated by political instability and the economic difficulties of the 1970s and 1980s. At many times, local plans could not be fully implemented because no particular unit - district or national - was responsible. There was also a widespread lack of key competent and skilled personnel. Other factors such as lack of training and capacity-building, along with growing divisions along tribal and regional lines also contributed to the inadequacy of centralization. The new government proposed decentralizing governance of public services as a panacea for all these challenges.

\section{Objectives of the Decentralisation Process in Uganda}

The government of Uganda perceived many benefits of decentralizing educational governance. It conceived that with decentralisation, it could achieve a number of results : (a) eliminate 
what it saw as unnecessary bureaucratic channels, (b) reduce corruption by minimizing the number of office levels to be consulted, (c) boost the level of monitoring since there would be physical proximity of local governments, (d) manage the education system according to local priorities, (e) improve financial accountability since local people and personnel would be motivated to monitor local governance, and (f) raise local revenue to fund services.

In 1998, the government embarked on strengthening the decentralisation system in order to improve the management and delivery of elementary education services. This clearly illustrated a shift in the roles. The districts ceased to be mere implementers of central government policies. The district staff base was expanded beyond supervisory roles to engage in spending, accounting, planning, budgeting, monitoring and evaluation. They now receive capitation grants from the central Ministry of Finance and Economic Development (MoFED). These funds are spent and accounted for according to guidelines provided by the national Ministry of Education and Sports (MoES). District councils also prepare district capacity-building plans and budgets. Each district, as a member of the national education planning process, prepares sector plans for district capacity-building. They draw plans such as for classroom 
construction and resource acquisitions that have to be approved by

MoES. These district plans and budgets increasingly contribute to the central MoES planning and budgeting. Clearly, the Ugandan government has radically devolved the governance of education to local governments.

Since educational decentralisation was part of a wider political reform, it is unlikely that careful thought was given at the planning stage to the far-reaching educational implications of decentralisation and to how it would be interpreted in practice. It appears that decentralisation laws preceded workable models of decentralisation. Although phasing in decentralisation allows for experimentation and the possibility of revisions, Uganda chose the all-at-once strategy. All the districts took responsibility for their education systems, whether they were ready or not.

\section{The Ugandan Education System Post-Decentralisation}

Although decentralisation was phased in quickly at the regional level, at the school level decentralisation appears to have proceeded more slowly. For elementary schools, the District government is the highest point of reference and authority. Local authorities have financial control and general decision-making powers over elementary schools. The schools are accountable, through the 
subsequent levels of governance, to the DEO. This system of powersharing has made decision-making quick and easy. But one wonders about the challenges that come with easy and quick decision-making in a developing system. At times, decisions about education issues are made by personnel who have little experience in education governance. The success of decentralisation depends on the question: How have education policy makers addressed the challenges that come with local governance in a country where resources are neither adequately nor evenly distributed? One way has been to strengthen both the central and local administrative infrastructure in support of educational decentralisation.

\section{i. The New National Governance Structure}

In 1998, the Ministry of Education also underwent post-constitutional restructuring. The central government began strengthening the infrastructure and the institutions at MoES. Many new national institutions were created. The central government retained the responsibility for policymaking, preparation of central budgets and planning. The central government also monitors and evaluates the different nationwide activities, especially compliance and accountability for funds disbursed. But, as a national government, it now concentrates more on planning, policy analysis, curriculum and 
DECENTRALISATION AND EDUCATION IN AFRICA

examination reform, national assessment, and monitoring and

evaluation.

Before decentralisation, three semi-autonomous institutions existed:

1. National Curriculum Development Center (NCDC)

2. Uganda National Examinations Board (UNEB)

3. National Council for Higher Education (NCHE)

These institutions were responsible for curriculum and examination reform, national assessment, monitoring and evaluation, and higher education, respectively. Under the new structure, the MoES comprises eight departments that cater to planning and policy analysis:

(1) Finance and Administration

(2) Education Planning

(3) Pre-primary and Primary Education

(4) Secondary Education

(5) Teacher Education

(6) Business, Technical, Vocational Education and Training (BTVET)

(7) Special Needs Education, Career Guidance and Counseling

(8) Higher Education 
A commissioner heads each department. Many units also have subdepartments. Further, the following were established:

(9) Policy Analysis Unit

(10) Resource Center

At the same time, three other technical units were approved as part of the establishment:

(11) Procurement Unit

(12) Construction Management Unit

(13) Instructional Materials Unit

In addition to many institutions that existed before decentralisation, there are several semi-autonomous institutions that have been established to handle more specialized functions of the Ministry:

(14) Education Service Commission (ESC)

(15) Education Standards Agency (ESA)

(16) National Council of Sports (NCS)

(17) Public Universities (i.e., Makerere University, Mbarara University of Science and Technology, Kyambogo University and Gulu University)

(18) Makerere University Business School (MUBS)

(19) Uganda National Council For UNESCO 
Many programs have been put in place to facilitate decentralisation of education service delivery, including:

(20) Education Strategic Investment Plan (ESIP)

(21) Universal Primary Education (UPE)

(22) School Facilities Grant (SFG)

(23) Teacher Development and Management System (TDMS)

No institution was eliminated: NCDC and UNEB still exist, and NCHE was transformed into a department and two institutions.

Many activities are coordinated by multiple units, institutions and departments. For example, to review the curricula, government set up a task force that involved different actors mainly at the Ministry. MoES outlined its aspirations for the new curriculum before forwarding the responsibility to the NCDC (Country Report, MoES, September 2003). Evidently, support structures with defined roles are in place to support the implementation of decentralisation of education. For instance, ESIP is responsible for building the capacity of district and local governments effectively and efficiently to deliver public educational services and to assure the quality of privately delivered services. The TDMS program is intended to improve quality and equity in the provision of elementary education through improved teacher training, development and professional 

support.

In the process of building local devolved systems, centralized bureaucracies were inevitably strengthened. Strong central regulation in such areas as curriculum design, assessment, teacher development and higher education remained. This is not surprising for a country where political and economic motives were central to decentralisation. Naidoo (2002) dubs this as a case of intense state control of some functions being coupled with greater decentralisation of other aspects. It is centralized decentralisation. The co-existence of both processes is very supportive but is not without contradictions. It is likely to produce lived tensions for school principals, teachers, parents and the local community.

\section{ii. New District Governance Structure}

At the district level, some institutions were created to support the office of the DEO. With decentralisation, key personnel in the district include: the Chief Administrative Officer (CAO), who is the district accounting officer; and the District Inspector of Schools (DIS), whose work is more pronounced at the elementary level. The DEO remains the head of the education department at the district to whom the head teachers (school principals) are answerable. 
DEO, operate under the control and supervision of CAO. CAO is an appointed member to the tier V District Local Council (DLC). The DLC is the main budgetary unit in the district.

The DEO is now directly answerable to the CAO, whereas in the past the DEO was answerable to the Permanent Secretary at the Ministry of Education. The DEOs are responsible for monitoring and supporting all schools within their districts, and they work with the CAO to develop plans and budgets. Through the DSC, each district recruits and assigns elementary school teachers, as they do other public servants. The $\mathrm{CAO}$ receives funds for education in the form of school staff salaries, funds for school supplies and grants, which are dispatched to principals through the DEO. From the time elementary education was universalized, the central government has been responsible for funding elementary education under the UPE program.

By law, finance and administration are decentralized for elementary, secondary, and technical levels (Wamala 2004). In practice, the shift in roles for the MoES from delivery of education to policymaking, investment management, and quality assurance is only at the elementary education level. Policy, budgeting and planning for secondary schools are not yet decentralized. Elementary schools report to the DEO and receive communication from the 
District Headquarters, but secondary and tertiary schools still primarily report to the Director of Education at the central government who then is answerable to the Permanent Secretary.

In secondary schools, it is mainly the salaries of teachers and the capitation grant that are channeled through the decentralisation structure. Other issues regarding secondary education, such as the recruitment and transfer of teachers, remain the responsibility of the ministry. As regards inspection, there is ambiguity as to whether the District Inspectorate staff has anything practical to do with secondary schools. There is also a question about whether these staff are qualified enough to inspect secondary schools.

Decentralisation has had almost no effect on pre-elementary/ kindergarten education and day care. This level of education remains in the privatesector.

\section{iii. Financial Decentralisation of Education Delivery}

In many Latin American and Caribbean countries, educational administration has been decentralized. Educational finance has also been decentralized, but to a lesser extent. In Uganda, financial decentralisation is in the lead. 
Structure of Central Education

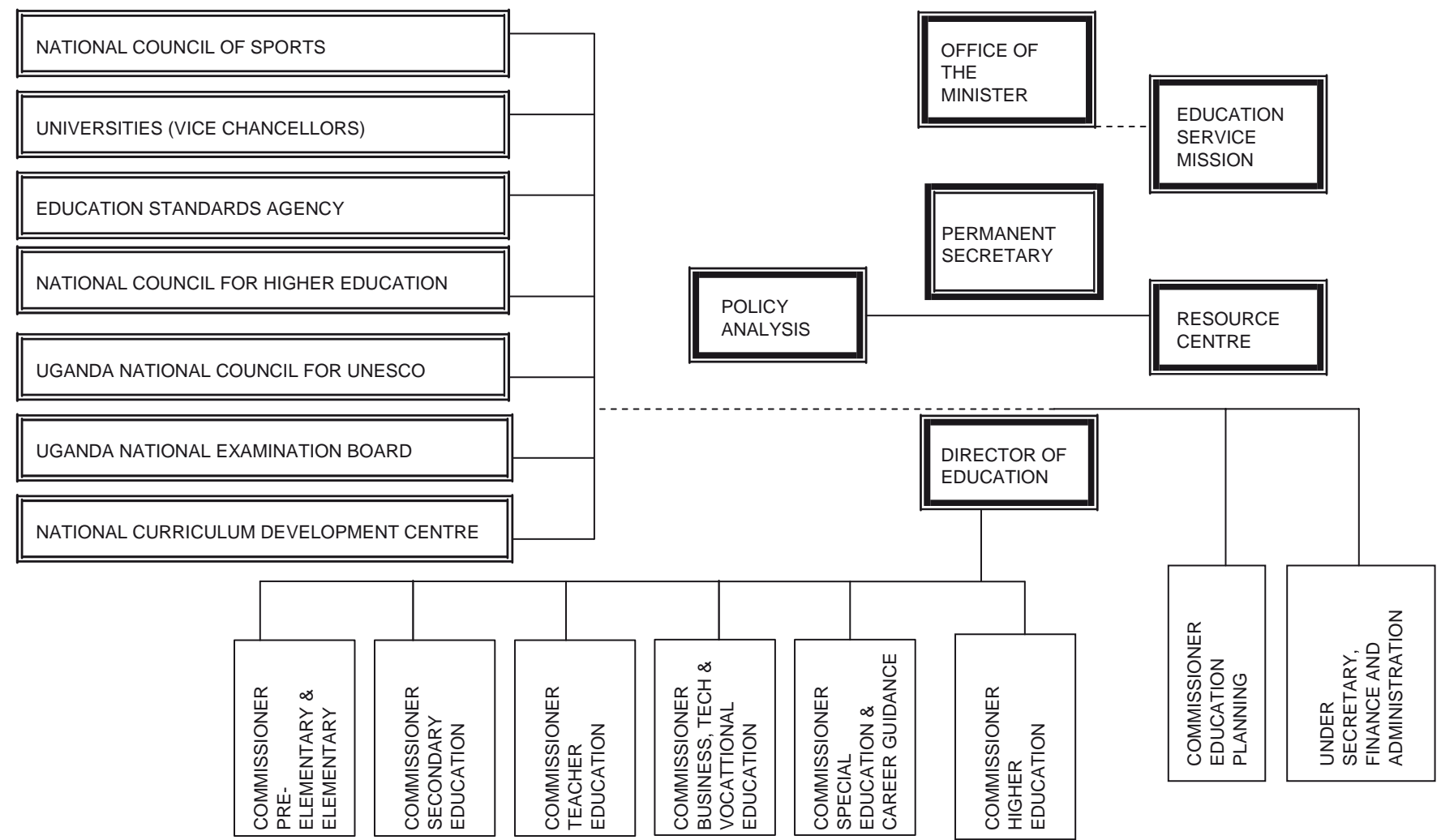


Through financial decentralisation education grants are calculated centrally and then released to the districts as conditional, non-conditional or equalization grants. Equalization grants are paid to local governments for giving subsidies or making special provision to the least-developed districts (Local Government Act 1997, Sect. 84(4)). Conditional grants are budgeted for as capitation grants that are distributed to the schools in accordance with their enrolments. Capitation grants are spent on instructional and scholastic materials, co-curricular activities, school management and administration. Whereas a number of these are donor- specific initiatives, elementary teachers' salaries, classroom construction, school capitation grants, support for the TDMS, and funds for instructional materials are provided through a special program, the general Poverty Action Fund (PAF). PAF is the main source of financial support to elementary education. Currently, about $75 \%$ of the total PAF transferred for education and $72 \%$ of all government resources for education are provided through the districts (US Agency for International Development 2000).

Among conditional grants are a variety of special expenditures aimed at supporting the curriculum: SFG, grants for teacher salaries for elementary schools, UPE grants, and Instructional Material Grant (IMG). The ministry sends funds for secondary school teacher 
salaries to schools through the district whereas salaries for elementary teachers are part of conditional grants that the district receives from the central government. The SFG supports communities' efforts to improve the accessibility and quality of elementary school education. The target is to achieve better classroom facility ratios, which include a teacher-pupil ratio of 1:55, a desk- pupil ratio of 1:3, a latrine-pupil ratio of 1:40 and at least four teachers' houses per school (Ministry of Education and Sports 2003a, b, c, d). The UPE capitation grant provides less than $\$ 10$ per child per year for children who are in their first 3 years of elementary education. UPE grants and the IMG are aimed at providing adequate quantities of good quality instructional materials. The $\mathrm{CAO}$ receives and ensures the prompt disbursement of education grants to schools. The CAO accounts for these funds in a proper manner, and ensures that conditional monies such as the UPE grants are not diverted to other needs. Diversion of funds, especially at the school level, is a common challenge.

Provision of infrastructure involves many activities and actors. The major activities include planning, budgeting, release of funds, accounting, reporting, monitoring and evaluation. These activities are carried out at different levels - school/local community; subcounty, division, district and MoES - by other actors concerned, 
such as MoFED and the President's office.

The involvement of the local community that originally occurred through the Parent TeacherAssociations (PTAs) now takes place through the School Management Committee (SMC). The two co-exist with varying powers. These committees are empowered to be co-signatories with the head teacher on school. They oversee school administration, development and improvement projects. SMC is intended to be the increasingly empowered governance mechanism dealing with education locally. Together with the local communities, SMCs are responsible for the preparation of the annual school work plan, which they submit to the subdivision council.

The unique structures through which centralization has been strengthened and decentralisation implemented appear beneficial. Devolution, the higher extreme of decentralisation, is said to have a low risk of long-term failure. The layered structures defined above may nevertheless present great risks for the Ugandan education system.

Decentralisation has been practiced for almost a decade in Uganda. In the next section, we will draw on the literature on decentralisation to theoretically tease out strong aspects and weak points of the Ugandan education decentralisation process. Even though no experimentation phases were built into the process, analyzing the benefits and risks of the implementation structures is 
likely to allow us to learn from experience. Where professional will is led by political will, there are likely to be large gaps between the proclaimed policies and implementation practices. Uganda can learn from countries such as Spain and Nicaragua where educational reform policy, not national law, guided the process. For Caribbean and Latin American countries where national law guided the decentralisation reform, such an analysis will help policymakers to assess the benefits and risks of decentralisation work as an educational reform.

\section{Benefits of the Decentralisation Process}

As a result of the progressive provision of capitation grants to all government-aided elementary schools, enrolments increased from three million in 1997 to over seven million in 2002. The implementation of the UPE program has meant an increase in resource flows from higher government in terms of grants, materials and construction funds. Many funding agencies are more comfortable dealing directly with specific Ministries and with local communities. Both the central and local education infrastructures are stronger today than they were before decentralisation. Some least-developed districts such as Kalangala are benefiting from the equalization grant. Community involvement in decision-making is encouraged through 
school level policy-making by the SMC and LCs. A detailed analysis of the Ugandan reforms shows that, in fact, some sub-county government officials are well aware of the preferences of parents. They fulfill them when institutional rigidities do not prevent them from doing so. In many schools, especially the missionary-founded schools and boarding schools, there was previously a lack of community involvement. With most administrative roles retained by the ministry and the district, the perceived benefits of decentralisation might not come to pass. For example, increased community participation may not necessarily result in increased choice and diversity.

Diversion of funds, irregular payments and decayed arrears plagued the education system into the late 1990s. Because of corruption among officials and slackened management measures, there were chronic inefficiencies in transferring teachers' salaries from the central government to district governments and then to the schools. Even getting new teachers appointed, posted and then enlisted on the payroll took years. Teachers would teach for years before they got their first salary. Salaries were terribly low. Salary arrears accumulated and some were written off after decades. Some teachers quit the teaching profession to try alternative means of survival, others taught at private schools in addition to the public 
schools where they were posted. In rural areas, many teachers took on casual labor jobs, opened up kiosks, or farmed to supplement their incomes. PTAs attempted to fill the gap by remunerating teachers and funding schools. This escalated the inequalities among schools, as parents of some schools were middle-class. Also, this lowered the teacher's professional status as parents became employers of teachers.

With the devolution of responsibility for elementary education to the district level, teachers' salaries are now paid more promptly and the management of the payroll has improved. District administrators can manage their funds without being slowed down by the bureaucracies of the central government. Elementary school teachers are appointed, posted and remunerated over a period of no more than 6 months. (This is not yet the case for secondary school teachers, who suffer a recruitment freeze and are still appointed centrally.) Remitting teachers' salaries through banks circumnavigates the diversion of salaries and other risks involved in cash payments. Prompt remuneration undoubtedly reduces teacher burnout, increases teacher retention rates and boosts teachers' motivation and status in the community (Saito 2000).

Gershberg and Winkler (2003) notes that information on the conditional grants to districts is published in the national press and 
provided to schools. District headquarters are required to display publicly the amount of UPE funds received and how they are planning to allocate them. Schools and sub-counties, in turn, must publicize their budgets and sources of funds. Monitoring and evaluation measures are put in place at all levels. The technical assistance units support the move from control to efficiency that came with decentralisation. Further, there appears to be structural collaboration among major national institutions such as the Planning, Local Government and Education Ministries, along with the President's office.

\section{Administrative Risks of the Decentralisation Process}

Geographic decentralisation in Uganda has involved both the existing districts and the new districts created by the process. Many existing districts had some form of infrastructure, revenue and power. Thus, the devolution process was somewhat supported. However, some existing problems of administrative weakness and inequity were imported into the new system. Even when the government has invested a lot of funds in infrastructure, there is a chance that weak and new districts might be run on informal and personal principals such as whose child are you, and that rules may be poorly followed and policy implemented less rigorously. This has 
been the case in developing countries in Latin America. The same is true in Uganda. Preparing new districts to take on their responsibilities goes beyond preparing the physical infrastructure. Readiness checks need to be put in place to ensure sufficient trained personnel along with financial and community participation at the local level.

It may appear more equitable to decentralize all regions at the same time and pace. However, this method assumes that decentralisation does not require a foundation. No time is allowed for experimentation and adjustment. Weaker and new districts do not get the opportunity to learn from stronger districts. Hanson (1998) warns that all at once decentralisation may send a country into some form of chaos for the implementers. Even Spain, a developed country, implemented its decentralisation program in phases.

Privatization and support for private schools introduce new choices and diversification. Some schools, especially those that claim to be international, follow non-Ugandan policy and have their students learn non-Ugandan syllabi such as the Cambridge syllabi. With the establishment of over twenty new departments, institutions, programs and technical units, tools to safeguard the national educational policy appear to have been strengthened. As in Spain, decentralisation is not likely to fragment the education system in Uganda because a lot of 
policy is still done at the national level. However, there is little chance that diversity and choice in schooling will be achieved. The national educational policy, school curriculum and syllabus frameworks, national assessment, teacher training and associated resource materials are still the ministry's responsibility.

Teacher education, especially in-service teacher education for administrators, teachers and participating community members, has been catered for by the TDMS and in the districts. Whether this professional development is taking into account the changing personal and professional needs of a decentralized system such as group dynamics, negotiation and public relations is a question that needs empirical study. In a US Agency for International Development (2000) report, it was noted that the quality of teaching and learning suffers from weak leadership and an irregular flow of resources.

Strengthening leadership and management of a decentralized education system requires work not only at the district level, but also at the sub-county and even the parish levels. Strategies are complicated, entailing not only training in technical skills such as budgeting and data monitoring, but also higher-level skills such as political leadership and cross-institutional collaboration. The number of districts whose capacity is inadequate for the tasks at hand multiplies the challenge. Another issue is whether and how to provide every 
district with a core teachers' college so that it can offer in-service training and other functions of the TDMS. This is where educationalists and education policy-makers may guide the politician to consider transferring primary teacher education to university faculties, as many countries are doing.

With both decentralisation and centralization occurring simultaneously, there is likely to be duplication of duties and resources. In a country where federal governments existed before centralization, one would hope that decentralisation would be synonymous with federalization. Instead, in Uganda federalization and decentralisation uniquely run parallel to each other. In tribal regions such as Buganda, which have relatively cohesive kingdoms, there is tripling of systems: centralization, decentralisation and federalization. Some duplication of resources has created depressing lived experience for teachers and students. One example is the introduction of district examinations for candidate classes. Learning and teaching now have to fit into the schedule of the regular school examinations, the district examinations and the final national examination. At the school level, this is turning teaching and learning into an examination-focused practice. 
Gershberg and Winkler (2003) argues that devolution produces centralization at the regional level, in part because sub-regional responsibilities might not be well articulated in the decentralisation legislation. This is particularly negative where regional officials are found to be less in touch than national officials with citizen preferences. The emergence of centralized districts is a growing issue in Uganda. Worse still, the districts are at times out of touch with what happens at lower levels; this works against the assumptions of decentralisation. With core education decisions around curriculum and school issues still centralized, either at the national or the district level, local community participation is still very limited.

Decentralisation expanded the overall size of the bureaucracies to include LCs. This expansion does not necessarily imply an increase in efficiency. There is evidence that bureaucratic delays and centralized inadequacies have been curtailed by decentralisation, but corruption seems to have multiplied. This is more limiting as corruption and non-professional management are now occurring at a minimum of three levels of governance: national, district and subcounty.

Some combined advantages of decentralisation and centralization are equitable allocation of resources and programmatic unity. These may be offset by diseconomies of scale, 
as seen in many Latin American countries. For a country with such a small national budget, subdividing it at sub-national levels inevitably increases administrative costs.

\section{Financial Risks of the Decentralization Process}

Funding criteria need to be looked into. Payrolls with ghost teachers and accountability data with ghost students and resources are commonly reported in the local Ugandan press. Local finance management has created monitoring loopholes. Central funding is facing limitations because needs are misreported as a result of central financing and reporting structures. Educational grants are provided on a per pupil basis. A common mismanagement method is to inflate the number of pupils in order to receive more funds. The reason why this malpractice continues unchecked is that correct data is not available (Royal Netherlands Embassy 2003). The Ministry of Education collects data annually through the Educational Management Information System (EMIS). However, misreporting makes it difficult to gather and aggregate educational statistics. In September 2003, the DSC Secretary of a new district, Kiboga, was remanded for putting "ghost teachers" on the payroll (Royal Netherlands Embassy 2003). 
of transferring finances from the central government to local governments. It is not rare for funds budgeted for one use to be diverted to another. Some resources have been diverted. In the Gulu district, for example, part of the Ush 2.6 billion (approximately 1.4 million USD) meant for elementary teachers' salaries was diverted in the financial year 1998-1999, and another part was embezzled. Also, funds for classroom construction were robbed during transportation.

Francis Lubanga, the Permanent Secretary Ministry of Education, admitted that Gulu had problems accounting for its SFG fund. The district is yet to account for Ush 918 million advanced for SFG between 1998 and the last year. The amount excludes the Ush 238 million on which CAO, Achiel Owori, is being questioned. (The New Vision, 23 August 2003).

Construction, resource and salary funds are misappropriated or their release to beneficiaries is deliberately delayed. Decentralisation creates new avenues for corruption. The corruption is tiered when deeper and systemic reasons for corruption in developing countries are not addressed. Education funds sometimes end up in private accounts of local government officials where they earn interest for the officials.

Different key stakeholders at various levels carry out monitoring activity for capitation grants. At the district level, monitoring and evaluation measures are put in place by the many ministries as well as by the President's office. The Ministry of 
Education visits the district at least every 2 months to verify compliance and to appraise the district progress in the SFG implementation. The district monitors and evaluates the performance of schools and contractors. Monitoring is carried out at the school level by the DIS. The LCs and the SMCs do daily monitoring and evaluation of contractors and of the schools as well. At the school level, head teachers are usually responsible for malpractice, delay or nonpayment of wages, misappropriation of grants and outright theft (Royal Netherlands Embassy 2003). The monitoring level is evidently retroactive and therefore needs to be supported with other proactive measures. In relation to procurement, the School Facility Grant (SFG) is plagued by corruption in the Classroom Construction Program (CCP). Although primary schools have little capacity to plan and account for expenditures, the schools are responsible for selecting and overseeing local contractors, with the assistance of the district assistant engineer and other district personnel. Schools are responsiblefor applying the funds, hiring a suitable contractor, supervising the work, paying the contractor, and ensuring the maintenance of services delivered. In 2001, an SFG evaluation was carried out. Different construction elements, such as doors and roofs, were monitored for their quality. The outcome of the quality evaluation showed that out of 35 classroom projects only 14 showed 
no shortcomings. 63

On September 3, 2003, it was stated in a Special Audit Report from the Auditor General's office that out of Ush $238 \mathrm{~m}$ remitted to the Gulu district for the Schools Facilitation Grant, only Ush 17.2m was put to use. Ush $40 \mathrm{~m}$ was unaccounted for, another $178.5 \mathrm{~m}$ was reimbursed to the Ministry of Finance, and Ush 3.1m was spent on bank charges (New vision, October 01, 2003).

There have been cases where education officials have been arrested for bribery when dealing with corruption cases.

The principal of Moroto Core Elementary Teachers College has been arrested for allegedly attempting to bribe officials from the Inspector General of Government to suppress a case. ... [together with the bursar, he] attempted to bribe the officials with Ush 1 million shillings. The duo was summoned by the IGG for several other allegations, concerning mismanagement of college funds and failure to give allowances to their tutors (Sunday Monitor, 12 October 2003, p. 4).

Not all districts registered the activities for which the funds were utilized. (This is reflected in the district profiles). Some districts did account for the capacity-building funds (PAF report, April 2003).

Parliament has considered alternatives for decentralizing the selection, procurement and distribution of textbooks. In light of the rampant corruption and mismanagement at both the school and district level, parliament decided to maintain centralized textbook procurement (US Agency for International Development 2000). Work needs to be done with the development and distribution of 
textbooks.

In addition to boosting accountability, participation procedures need to be strengthened. There is a need to check situations where perceived benefits to the communities and to marginalized districts and stakeholders have been captured by the already privileged.

In a way, devolution of responsibility is also a form of pushing resource burdens to lower levels. A worst-case scenario might arise years down the road, when local districts will be required to fund their public services. This would be a disaster for low-revenuegenerating districts, which are in the majority in rural areas.

Hopefully, educational reform will never place the local community level in a situation where they feel over-burdened with financial responsibilities.

Even though international donor agencies encourage decentralisation as a way of reducing the national debt, it is not evident that decentralisation solves the problem of limited central financial resources. The generation of more resources at the local level faces management and resource base inadequacies. The local tax base is very small in many rural districts. In some old districts that have been split, the revenue sources have dwindled as new districts sap the resource base of older districts. 


\section{Political Risks of the Decentralisation Process}

Educational decentralisation is complex and might be different from other forms of decentralisation; it requires the will and strength of numerous systems, institutions and personnel. Educators might wish to work at a shared vision, including perceived outcomes and feared shortcomings of this reform at all levels, including the community level. Since the Ugandan decentralisation initiative was part of a larger political move, there are likely pockets of passive resistance among the actors. With the numerous units and departments in the Ministry of Education, along with tiered local governance at lower levels, one hopes that reform initiatives will not be diluted at every level in Uganda as they were in Venezuela (Hanson 1998). To encourage participation in reform initiatives, the Ministry should ensure that this is a win-win situation at both the local and national levels. Transferring positive financial and non-financial opportunities to the districts and subsequent levels is the key. Hanson (1998) has identified wide collaboration as a component of successful decentralisation. The Uganda national government has not dumped financial and administrative burdens onto the districts as Argentina did (Hanson 1998).

With decentralisation, the government replaced PTAs with 
broader councils, SMCs, which include members of the community. It was a political decision, not an educational one, to remove power from the PTA as an influential group that had started subsidizing teachers' salaries and other school expenses. As the PTA's power is removed, whether or not the local community will rise up to participate in the SMCs depends on the level of establishment of the school and whether it is a boarding school or a private school. Although disempowering PTAs appears to be a way of keeping a balance between parental and community participation, many villages contain schools in which their children cannot afford to enroll. SMC committees might therefore not have any representation from parents of students at such schools. Balance between parental and community involvement is only achievable at a village school.

Councilors are elected positions in all five tiers. The President reshuffles the cabinet regularly. In countries where this is the case, it has been observed that the planning and implementation of decentralisation is disrupted by the constant top- level personnel changes. In Uganda, the Minister of Education and the state ministers at different levels of education have all regularly been reshuffled. Top-level policy makers in education are usually not educators by profession. 


\section{Educational Decentralisation as an Educational Reform}

Given Uganda's background of political and economic instability, and the continued instabilities in some areas of the country, a balance between national crisis and political stability is a factor in the success of decentralisation. One hopes that, with any change of governance, the next political leaders will have the will to evaluate the successes and failures of the decentralisation reform initiative.

Decentralizing the education system in Uganda makes sense as a politically motivated development. Its benefits are evident.

Decentralisation has led to increased enrollment and resource flow at the elementary level. Educators need to determine how to maximize the benefits of the process. More infrastructure and analyses need to be put in place to ensure that the perceived benefits such as increased diversity and community participation are realized. It is in this way that the educationalists will turn this political and economic agenda into a curricular reform.

Educational leaders and personnel at the various levels will continue to be challenged by the implementation of decentralisation. There is a need to work through the conceptualization of decentralizing education, to identify and eliminate impediments to its effectiveness. There is need to reflect on the inherent risks of 
decentralizing, much less privatizing, important services such as education. Although it might be the case that delivery of feeder roads, as a basic service, is facilitated by decentralizing governance, education service delivery is much more complex.

\section{Conclusion}

In the transition period from centralized to decentralized education delivery, clarity over roles and responsibilities has been a problem. This has been especially so between the CAO, DEO, and LCs at lower levels. Consider that some district staff such as the district assistant engineer report directly to the MoES whereas others report to the CAO. There is also an uncertain relationship between staff of the TDMS and the DEO. This lack of clarity at the TDMS may not facilitate the tailoring of personnel training to the needs of the district. The responsibility of the Coordinating Center Tutor (CCT) at the district has come into question: some DEOs want the tutor to report to the district administrative office rather than to the Elementary Teacher College (PTC). More explicit defining and some revising are needed to eliminate confusion about responsibilities with respect to reporting, management and accountability.

There is a concern that over-proliferation of conditional grants is not promoting good governance and has a negative impact on 
service delivery. The conditional grant for construction SFG functions reasonably well, but it has an unclear relationship with the Local Government Act. The UPE capitation grant suffers from serious delays at the district level, and from non-compliance with administrative guidelines (US Agency for International Development 2000). Guidelines for both the grants are seen as excessively rigid. A number of reforms have been directly affected by decentralisation. Decentralizing education raises questions, some of which are unique to developing countries. With the population size of Uganda at 25 million people (Food and Agriculture Organization 2005), decentralizing governance seems helpful. However, the size of the country in terms of area and GNP does appear to warrant regional and economic decentralisation. It is a mistake to perceive decentralisation as a blanket panacea to problems of political and economic instability.

\section{Authors}

I.K. Namukas ( $\square)$

Faculty of Education, University of Western Ontario 1137 Western Road London, Ontario, N6G 1G7 e-mail: inamukas@uwo.ca

R. Buye, Makerere University 


\section{References}

Berry JW, Wood J, Odaet K, Balemesa T (2003) Local solutions to global challenges: Towards effective partnership in basic education. Country Study Report - Uganda. Netherlands Ministry of Foreign Affairs, The Hague.

Food and Agriculture Organization (2005) Education for rural people in Africa: Policy lessons, options and priorities. Ministerial seminar hosted by the Government of Ethiopia. Food and agriculture organization of the United Nations, report by Marcelino Avila \& Lavinia Gasperini. http://www.fao.org/newsroom/common/ecg/107444/en/paper.p df. Accessed 31 Jan 2006

Gershberg AI, Winkler D (2003) Education decentralisation in Africa: A review of recent policy and practice. http://info.worldbank.org/etools/docs/voddocs/490/946/africa.d oc. Accessed 31 Jan 2006

Golola M (2003) Reforming Africa's institutions: Towards a domestic response. The challenge to local bureaucracies in Uganda. Inter-university council for East Africa/Kampala/ Uganda. http://www.wider.unu.edu/events/book-launch-rai-17feb-2003/presentation-mg.pdf.Accessed 31 Jan 2006 
challenges. Occasional paper series no. 9. Partnership for

Educational Revitalization in the Americas, Santiago.

http://www.thedia- logue.org/publications/preal/preal9en.html.

Accessed 28 Nov 2005

Hanson ME (1998) Strategies of educational decentralisation: Key

questions and core issues. J Educ Admin 36(2):111-128

Inter-American Development Bank (2000) Reforming elementary

and secondary education in Latin America and the Caribbean:

An IDB strategy. Sustainable development department. Sector

Strategy and Policy Papers Series. Inter-American Development Bank, Washington, DC.

Lugumba SME, Ssekamwa JC (1973) Education development and administration in Uganda 1900-1970. Longman's Limited, Kampala.

Mathonsi V (2001) Transforming governance and management of education - The case for South Africa: Panel presentation at the South African Democratic Teachers Union (SADTU) Policy development conference. Gallagher Estate, Midrand-Gauteng: South Africa. http://www.sadtu. org.za/press/speeches/2001/155-2001.0.htm. Accessed 31 Jan 2006

Ministry of Education and Sports (2003a) Draft report on a case study on the impact of UPE on the quality of basic education in 
Uganda, by Mulyalya C, Arach A, Nantume O, Zalwango C.

Kampala, Uganda: MOES.

Ministry of Education and Sports, Uganda (1998) Education

Strategic Investment Plan 1998-2003.

http://www.usaid.or.ug/SO8\%20annexes/Education\%20Sector

\%20 Investment\%20Plan\%20(ESIP)\%20-1998-2003.doc

Summary at http://www.education.go.ug/ strategicPlan.htm.

Accessed 31 Jan 2006

Ministry of Education and Sports (2001, May) The development of education in Uganda in the last ten years. Report on the development of education for the 46th session of the international conference on education, Geneva, Switzerland.

Ministry of Education and Sports (2003b, April) Final report on monitoring and evaluation of PAF programmes, in 30 districts of eastern and Central Uganda. http://www.education.go. ug/PAF\%20Report.htm

Ministry of Education and Sports (2003c, May) Final draft report on a case study on the impact of TDMS on the quality of basic education in Uganda. http://www.education.go.ug/tdms1.htm

Ministry of Education and Sports (2003d, August) Monitoring district implementation of programmes under poverty action fund (PAF) In the education sector. A report on the monitoring 
exercise carried out in 23 districts and 13 municipalities, April -

August 2003. http://www.

education.go.ug/PAF\%20Report\%20(Aug\%202003).doc

Ministry of Education and Sports. Final draft report on a case study on the impact of strengthening planning, management and implementation on the quality of basic education in Uganda. http://www.education.go.ug/planning,_management_and_impleme ntation.htm. Accessed 31 Jan 2006

Naidoo JP (2002, March) Education decentralisation in sub-Saharan Africa-espoused theories and theories in use. Presented at CIES annual conference. University of Central Florida, Florida.

Paige JR (2000) Preserving order amid chaos: The survival of schools in Uganda, 1971-1986. Berghan Books, Herndon.

Royal Netherlands Embassy (2003) Uganda: The fight against corruption. A case study on the prevalence of corruption in Uganda, specifically in local government, education, justice, law \& order, and procurement. Kampala, Uganda, Report by Sandra Zwart. http://www.u4.no/ document/showdoc.cfm?id=94. Accessed 31 Jan 2006

Saito F (2000) Decentralisation for participatory development in Uganda: Limitations and prospects. Journal of Intercultural Communication, Ryukoku University. http://www.world. 
ryukoku.ac.jp/ fumisait/en/jic2000.pdf. Accessed 9 Dec 2005

Ssekamwa JC (1997) History and development of education in Uganda.

Fountain Publishers, Kampala The Republic of Uganda (1997)

The Local Government Act.

US Agency for International Development (2000) Support to

Uganda primary education reform: Final report. The basic education and policy support (BEPS) activity. Jeanne Moulton. http://www.beps.net/publications/SUPPORT\%20TO\%20UGA NDA\%20PRIMARY\%20 EDUCATION\%20REFORM.pdf. Accessed 9 Dec 2005

Wamala P (2004) Decentralisation and its effect on education service delivery in Uganda. A case study of Mpigi district 1993. 